\title{
Equilibrium
}

Quarterly Journal of Economics and Economic Policy

VOLUME 8 ISSUE 1, 2013

ISSN 1689-765X

Jolanta Gałuszka*

Cracow University of Economics, Poland

\section{The Fiscal Union as a Remedy For the Economic and Financial Crisis in the European Union}

JEL Classification: $E$ 6, $G 01, G 02, H 2$

Keywords: tax competition, fiscal union, globalization of tax policy

\begin{abstract}
Financial crisis and a global deep recession has led to new government interventions, and the nation's governors have struggled with the resulting budget deficits, unemployment, and other economic problems in their states. Many states are facing major fiscal problems in coming years. Rising debt and growing health and pension costs threaten tax increases down the road. At the same time, intense global economic competition makes it imperative that states improve their investment climates. To that end, some governors are pursuing broad-based tax reforms, such as cutting income tax rates and spending restraint to get their states back on track. The purpose of the article is to identify the impact of globalization and the international environment on the process of tax harmonization in the EU from the perspective of proposal to establish a fiscal union. Moreover, I would like to answer whether a deeper fiscal harmonization will help to achieve the objectives of fiscal consolidation in the time of global tax competition and free movement of capital, goods, services and labour force. The article is divided into several small parts. These parts include the examples/small case studies, which would help stressing the pros and cons of fiscal union and its potential consequences also in the field of economic freedom. Methodology in the article is based on the descriptive analysis of statistical data, source materials and Polish and English literature.
\end{abstract}

(C) Copyright Polish Economic Society Branch in Torun

Date of Submission: January 8, 2013; date of acceptance: February 26, 2013

*Contact: Jolanta.galuszka@ue.katowice.pl, Uniwersytet Ekonomiczny w Katowicach, ul. 1 Maja 50, 40-287 Katowice, Poland 


\section{Introduction}

Since 2007, the economies around the world have been experiencing the effects and the consequences of the global collapse which are visible both in the private and public sectors. Economists have sounded the alarm on the financial and economic imbalances which had been growing throughout most of the decade and some have predicted recessions and crashes.

The negative consequences of the crisis ${ }^{1}$ with the absence in the discipline of public finance have led to the extensive and deep decline in the state public credibility. The support for major reforms in the economy, including public intervention has become almost omnipresent, leading to general destabilization of the public finance. The question is whether the next stage of the EU integration - a fiscal union - can effectively resist the changes in the international area and ensure the discipline in the public finance of each individual country.

Fiscal consolidation, according to OECD analysis, is defined as concrete policies aimed at reducing government deficits and debt accumulation. Such actions, however, must have their own financial base. Tax becomes a key element in the consolidation programmes. The tax policy plays a special role in shaping the investment climate in the country; it is a determinant of wellbeing of a society and determines trends and patterns of social policy. However, because of the ongoing process of globalization, sovereignty and autonomy of the state are subjected to the pressure from the international environment, which forces the adaptation to changing conditions. In the case of the European Union, there are two opposite processes: the integration including harmonization, which implies certain directions of behaviors reducing the different solutions to one common policy that concerns all member states, and the competition which is 'a lawyer" of the fiscal policy optimalization.

In the case of the fiscal policy it is difficult to find a compromise between harmonization and tax competition. The harmonization introduces similar solutions for 28 countries limiting in this way the instruments of stabilization and promotion. The tax competition in its positive aspects enforces the verification of the existing legislation helping to reduce irregularities in the public finance, including also the lack of the fiscal discipline.

\footnotetext{
${ }^{1}$ The recent global financial and economic crisis (originating in developed capitalist economies) has called forth many causal explanations, including excessive credit growth, unsustainable asset bubbles, inadequate regulation, defective economic policies, executive greed, flawed credit risk models, rating agency frauds and so on. All these are considered as secondary causes, because the primary cause is that they were allowed, or even encouraged, to happen and to develop unchecked (Sy 2012).
} 


\section{Coping with Globalization}

Globalization is a long-standing phenomenon that has accelerated spectacularly in recent years. For a few years, globalization has played a central role in discussions of politicians, economists and sociologists. It is not only a fundamental theoretical concept, but also political and ideological slogan, mobilizing supporters and opponents to particular policies. For the political right in the developed countries, globalization is a kind of ideological salvation. Right sees a threat to national state institution and the national identity culture in the process of globalization. Among researchers, there are differences of opinion on recognizing the nature of the globalization process. The controversies concern the sources of this phenomenon, its nature and type of social change, and what causes it. Giddens pays particular attention to the complexity of the phenomenon of globalization. According to him globalization is "the intensification of worldwide social relations which link distant localities in such way that local happenings are shaped by events occurring many miles away and vice versa", thereby changing all aspects of our everyday life (Giddens 1990, p. 64). Giddens also talks about four highly interrelated globalization dimensions: nation states, world military order, world economy and international division of labor.

Globalization is difficult to define. Some describe globalization as liberalization of trade flows and capital flows (Grunberg 1998, pp. 591-605; Fox 1998, pp. 95-105). Others focus on increased mobility factor as a sign of integration among countries (Grubert 1998, pp. 591-605). The OECD (2001) characterizes globalization as the "internationalization of production and sales and new forms of delivering goods and services to consumers across countries, new developments in information and communications technologies, and the growing importance of e-commerce." Among the many aspects of expressing the definition and differentiation of this process, accurate and consistent seems to be that one proposed by J. Stigliz. According to J. Stigliz, globalization is the field on which some of our major societal conflicts - including those over basic values - play out. Among the most importatnt of those conflicts is that over the role of government and markets (Stigliz 2007, p. 39).

But above all, globalisation is associated as a increasing trade and financial openness, with a particularly sharp pickup in capital flows (or financial globalization) in recent years. This has been accompanied by financial deepening as the financial sector has grown in economic importance. The ability of capital to move to where it can be used most productively, together with deeper domestic financial markets, can increase an economy's efficiency and growth potential. However, globalization and financial deepening can have consequences that require appropriate policy responses if higher growth is to 
materialize, and the ability to respond in part depends on how these developments affect the government's policy choices, including its fiscal policy options (IMF 2007).

Liberal conditions for the development of capital goods and knowledge prejudge about the globalization and its power. As a result, the market begins to operate not only within the national economy, but in the global economy. In this sense, globalization is a process of reducing barriers to market mechanisms operating across borders. The process of globalization is thus increased freedom of movement of capital, goods, factors of production between countries. It is a gradual disappearance of economic borders and qualitative jump in the mobility of production factors .

Globalization is viewed upon as a process of eliminating or at least limiting the various barriers that lead to the liquidation of the tools and methods of protection from external competition. This leads to a situation of putting people, companies, countries in front not limited competition, particularly outside the European Union legislation. While competition is primarily associated in the private sector for several decades, this phenomenon is reflected also in the public finances especially in tax policy, which has been subjected to pressure from the international environment.

The structure of tax systems and the amount of the tax burden are subjected to changes in the new fiscal architecture characterized by the free movement of factors such a: production, labor and capital. The private sector, which for years was forced to accept the rules of economic and social public policy has become, thanks to globalization, powerful in their own way in determining the directions of changes. For the private sector, globalization means that economic agents are faced with many more opportunities and much more intense competition than ever before, even in the field of tax policy. On the other hand, globalization also demands a drastically changed role of national governments ${ }^{2}$ (Mrak 2000, p. 8). The state monopoly was abolished in shaping the structure of tax systems and tax rates. However, in this freedom Tanzi sees fiscal termites, which can lead to the derogation of the public finances to guarantee certain rights, including social security so characteristic for European countries. These "termites" result from the interplay of globalization, tax competition and new technologies (Tanzi 2000, pp. 4-15), which combined with redistributive policies in excess of the financial

${ }^{2}$ Governments can respond to the increasing mobility of cooperation in either of two ways. They can try to fence in the existing corporate tax base with layers of new rules and regulations. Alternatively, governments can embrace globalization by cutting the corporate tax rate and simplifying the tax system. (Gałuszka 2010, p. 47) 
capacity of the budget leads to loss of sustainability of public finances and the "public danger" ${ }^{3}$ facing a few European countries.

A special role in such situations is attributed to the taxes and it seems that the use of them in the process of stabilizing economic fluctuations in the deficit and debt level is the most convenient (first of all for public authorities) instrument for improving the situation in the public finance. It is difficult, however, to expect social approval to increase the tax burden. It should be noted that the international community had time to get used to the gradual liberalization of the tax burden, specifically the relaxation of barriers to the free mobility of capital.

From the mid 80's. we have been witnesses of the liberalization of the capital account and unhindered financial flows which constitute the essential obstacle for the macroeconomic, global financial stability afflicting individual managements of strong economic fluctuations. Both integration and the globalization constitute the background for many changes extorting verification of the financial management both in the real as well as public sphere creating the financial global system. Such a situation is creating a considerable risk to the stability of the public finance as a result of the possibility to invest and allocate capital in the convenient fiscal jurisdiction ${ }^{4}$ and hence the outflow of tax revenues. With response to the race to the bottom and intensifying tax competition the solution seems to be Fiscal Pact. However, Ger-

${ }^{3}$ The definition of this concept is found in the Strasbourg case, the Lawless $v$ Ireland (judgment of 1 July 1961, complaint no. 332/57). This is a "crisis situation or unique and danger to the entire population and pose a threat to the organized life of the community forming the state." Clarification of this concept is also a judgment on Denmark, Norway, Sweden, the Netherlands v. Greece (judgment of 24 January 19 968, complaints no. 3321-4/67), where the European Commission of Human Rights has determined what is the situation of "other public emergency threatening the life of the nation ". This condition occurs when the following criteria are met: (1) The danger must be present and severe, (2) the effects of risk must involve the whole nation, (3) is at risk the continuity of the state of organized community life, (4) The crisis or danger must be unique, which means that the normal measures or restrictions permitted by the conventions to maintain public safety, health and order are totally inadequate.

${ }^{4}$ Tax scholars generally agree that taxes drive the decisions of multinational corporation. U.S. Treasury found that a country with effective tax rate 1 percent point lower attracts about 3 percent more capital. Based on this result, a 1 percentage point cut the effective tax rate on capital will increase foreign direct investment as a share of gross domestic product by 0,1 percent (Mintz 2008). We can find a substantial confirmation in academic studies. For instance, Hines finds that taxation significantly influence the location of foreign direct investment, corporate borrowing, transfer pricing, dividend and royalty payments, and research and development performance (Hines 1999). Desai concludes that multinational firms are extremely aggressive and sensitive in responding to taxes on the margins of avoidance, ownership, and investment (Edwards, Mitchell 2008). The same arguments finds Mintz, according to him high effective tax rates on capital result in less foreign direct investment and therefore less economic growth (Mintz 2007; Gałuszka 2011, p. 47). 
many, Great Britain and France have moved one step further in the field of tax competition, they initiated also works in the mentioned arena at the OECD level. In 2013 (February) the issue of the fight against the harmful tax competition resulted in the report "Addressing Base Erosion and Profit Shifting," (BEPS). OECD proposed to expand the international taxing powers of governments (OECD 2013). In order to address base erosion and profit shifting which is fundamentally due to a large number of interacting factors, a comprehensive action plan should be developed quickly. The main purpose of that plan would be to provide countries with instruments, domestic and international, aiming at better aligning rights to tax with real economic activity (OECD 2013, p. 51). According to D. Mitchell, the new OECD report calls for more tax rules on companies but does not acknowledge that governments already have immense powers to restrict corporate tax planning through "transfer pricing" rules and other regulations. However such coordinated action to raise taxes would come at the expense of economic freedom and economic growth (Mitchell 2013).

\section{Phenomenon of Globalization and the Impact on Tax Burden}

Globalization is widely attributed to fiscal revenue cuts especially from the traditional taxes, and set in motion forces that increase the collection from alternative, less traditional taxes. Governments are increasing their reliance on VAT/GST systems for economically sound reasons. Compared to income taxes, VATs are less affected by economic ups and downs and thus more stable, their revenue bases are less mobile, and their real-time collection provides a steadier revenue stream (KPMG 2011).

Certainly, globalization has a significant share in convergence of tax structure and tax rates across countries resulting in the phenomenon of tax competition. But the overall assessment of the impact of globalization on tax systems is diverse.

A few years ago, R. Neumann, J. Holman and J. Alm suggested that empirical evidence on the impact of globalization on tax policy remained quite mixed. Although, according to them, there have been some changes in the tax policies along the predicted line, to date these changes - on the level of collection, the composition of revenues, the convergence in tax rates - have been minimal (Neumann et al. 2003, pp. 2-5).

Currently, they present quite an opposite view. According to them, common perception is that globalisation implies that governments lose their ability to choose tax policies independently of other jurisdiction - in course of increase tax competition or increase tax harmonization. The level of tax rates 
is likely to decline, we can expect the changes in the composition of taxes, and jurisdictions cannot set tax goals, rates independently of other jurisdictions (Neumann et al. 2008).

Tanzi has no doubt that globalization trends to put downward pressures on the level of taxation. There are many reasons for this. Firstly, globalization and the opening of economies requires that foreign trade taxes be eliminated. Secondly, international tax competition has generated a significant reduction in the marginal tax rates for personal income taxes and for corporate taxes. Thirdly, the mobility of financial capital is forcing countries to reduce taxes on this important tax base. In some countries, this has led to the introduction of the dual income tax that taxes financial capital at lower rates. Fourthly, it has become difficult for countries to put high tax rates on luxury products because of the possibility for individuals to get these products from country where the rates are low (Tanzi 2004, pp. 2-5). Theories may experience cycles just as economies do (Tanzi 2005, p. 13).

It is really hard to say which changes in taxation were provoked strictly by globalisation but tax reform is an ongoing process. As globalization advances, individuals and business are gaining greater freedom to work and invest in countries with lower taxes. That freedom is eroding the monopoly power of governments and forcing them to reform their tax systems and restrain their fiscal appetites (Edwards, Mitchell 2008, p. 1). Tax system reflects changing economic, social and political circumstances. Over the last two decades, almost all OECD countries have undertaken structural changes (Table 1) to their tax system, which have significantly altered the way these systems function, and their economic and social impacts.

Table 1. Reducing tax rates - the most common reform feature in 2007 and 2008

\begin{tabular}{|l|l|}
\hline Reduced profit tax rates & $\begin{array}{l}\text { Albania, Antigua and Barbuda, Bosnia } \\
\text { and Herzegovina, Burkina Faso, Canada, China, Côte D'lvoire, Czech } \\
\text { Republic, Denmark, Dominican Republic, Georgia, Germany, Italy, } \\
\text { former Yugoslav Republic of Macedonia, Madagascar, Malyasia, } \\
\text { Morocco, New Zealand, Samoa, St. Vincent and the Grenadines, } \\
\text { Thailand }\end{array}$ \\
\hline $\begin{array}{l}\text { Simplified process of } \\
\text { paying taxes }\end{array}$ & $\begin{array}{l}\text { Azerbaijan, Belarus, China, Colombia, Dominican Republic, France, } \\
\text { Greece, Honduras, Malaysia, Mozambique, Tunisia, Ukraine }\end{array}$ \\
\hline Eliminated taxes & $\begin{array}{l}\text { Belarus, Dominican Republic, Georgia, Madagascar, Malaysia, Mexi- } \\
\text { co, South Africa, Uruguay }\end{array}$ \\
\hline Revised tax code & Bosnia and Herzegovina, Bulgaria, Morocco, Mozambique, Zambia \\
\hline $\begin{array}{l}\text { Reduced labour tax or } \\
\text { contribution rates }\end{array}$ & France, Mongolia, Ukraine \\
\hline
\end{tabular}

Source: Paying Taxes (2009, pp. 11). 
In some countries, for example, many of the Eastern European economies in transition, the reforms have been profound and implemented over a very short period of time. In others, most of the European countries, the reforms have been a gradual process of adaptation but which over time have substantially redesigned their tax systems. One can argue about whether this second group of countries can be characterized as having undertaken "fundamental" tax reform. Few would disagree that the tax systems in operation in the 30 OECD Member countries today truly are fundamentally different from those which operated in the mid 1980's (Owens 2006).

These tax reforms have been driven by the need to provide a more competitive fiscal environment and spur growth. Almost all the tax reforms of the last two decades involving the income tax can be characterized as tax rate reducing and tax base broadening reforms in particular the on wages, business profits, dividends, interest, capital gains, and wealth. Economic studies show conclusively that business taxes significantly affect investment in a country. Iowerth and Danforth (2004) suggest that a 10\% reduction in the cost of capital can increase investment in machinery and equipment by $10 \%$ in Canada. More powerful results have been obtained by studies on foreign direct investment (FDI), showing that a $1 \%$ reduction in the effective tax rate on capital can increase foreign direct capital stock by about $3.3 \%$ (Mooij, Enderveen 2003, pp. 673-93). In turn, Mintz and Tarasov indicate that one-percentage-point increase in foreign direct investment inflows to GDP raises the economic growth rate by 0.2 percentage points (Mintz, Tarasov 2007). Thus, high effective tax rates on capital result in less foreign direct investment and therefore less economic growth.

Revenue authorities around the world are making great efforts to streamline administrative processes and modernise payment systems. In the past seven years, more than $60 \%$ of the 183 economies covered by Doing Business, has recorded 244 reforms aimed at reducing tax rates, the time or cost to comply with tax laws. In 2010/11, 33 economies made it easier to pay taxes or reduced tax rates. Introducing electronic systems to make compliance easier was the most common feature of tax reform for the first time since 2004 (Paying Taxes 2012, p. 15).

But reducing corporate income tax rates has been the most popular reform feature. It should be emphasized that the loudest tendency to a gradual reduction of tax rates was recorded at the end of the 90s (Figure 1). More than 60 economies have done this (Paying Taxes 2009). Within the last 30 years, corporate tax rates have fallen from around $45 \%$ to less than $30 \%$ on average in OECD countries (Gomes, Pouget 2008). And lately, with increased mobility of multinational corporations, tax competition has intensified. The world's average corporate tax rate has fallen in each of the past 11 years, from $29.03 \%$ in 2000 to $22.96 \%$ in 2011 . Regionally we see that: The 
Asia Pacific Region average rate went from $23.96 \%$ in 2010 to $22.78 \%$ in 2011. The Latin America region went from $25.33 \%$ in 2010 to $25.06 \%$ in 2011. North America went from $23.67 \%$ in 2010 to $22.77 \%$ in 2011. Oceania went from $24.17 \%$ in 2010 to $23.83 \%$ in 2011 . Europe was the only region where we saw a slight increase - from $19.98 \%$ in 2010 to $20.12 \%$ in 2011 . The Africa Region remained flat. Based on these results, it seems certain that the decade-long era of sharply declining corporate tax rates is almost behind us (KPMG 2011).

Figure 1. The rates of tax on corporate income in OECD countries in 1993-2007

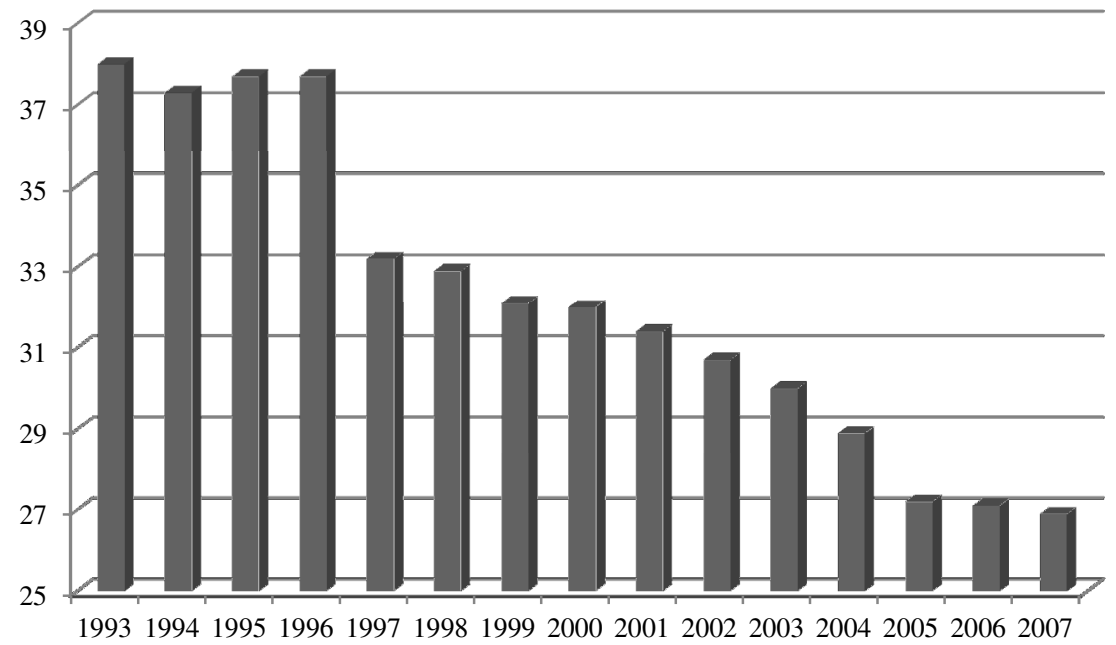

Source: KPMG's Corporate Tax Rate Survey (2008).

Internationalization of business processes makes the differences are gradually disappearing not only between countries but the whole economic groups and regions in the world.

Many countries have reduced also capital gains taxes as well. For instance, Canada and Germany lowered their capital gains tax by allowing individuals to exclude $50 \%$ of their gains from taxation, effectively cutting the tax rate in half. While the capital gains rate in the U.S. is $20 \%$, Austria, Belgium, the Czech Republic, Germany, Greece, Hong Kong, Mexico, the Netherlands, New Zealand, and Switzerland all have a zero individual capital gains tax rate. Reducing capital gains rates is important because start-up firms often rely on private equity from "angel" investors and others who fund risky companies. The payoff for these investors comes from a big capital gain on the few start-ups that succeed (Edwards 2003, p. 26). 
Currently, the EU countries have the lowest average rate of income tax from legal persons. In 1993, when the composition of the 15 countries entered the EU average rate were at $38 \% .14$ years later in the structures of the EU average fell by $13.8 \%$ reaching the lowest level of $24.2 \%$, which makes the Union European of the relatively attractive investment area. This result, however, consist of the newly adopted regulations of Central and Eastern Europe, where tax rates that are among the lower. This tax is therefore subject to tax competition between so-called old and new member countries and is an instrument to attract both investment and new jobs.

Among the EU countries, the biggest drop in the years 1993-2007 occurred in Germany, where the tax rate was reduced from 59.7\% in 1993 to $38.36 \%$ in 2007. Despite drastic reductions, Germany still have one of the highest tax rates in tax income tax, not only among the EU Member States but throughout Europe. For comparison, in Switzerland, this rate ranges from 13,12-21,3\% depending on the canton, while in Austria this is the rate of $25 \%$. The European leaders as matter of corporation tax rate level is also Italy with a rate of $37.25 \%$, and $35 \%$ of Malta and Spain, with a rate of $32.5 \%$.

By 2007, the largest reduction in income tax rates of corporation was carried out by Ireland. In the late 60's, when Ireland began making efforts to attract foreign investment - particularly from the U.S., Ireland introduced a zero rate of income tax on profits from exports, which was in force until 1980 , when it was replaced with a $10 \%$ proportional tax on companies which included within its scope all the personae of manufacturing companies. Under pressure from the European Commission, which accused the Irish of dumping tax rate was raised to $12.5 \%$, which is one of the most competitive solutions in the European Union.

Few countries can afford to lowering tax rates without suffering of any economic and/or social consequences. The problem focuses on the question whether a reduction in one category will not imply a tax rate increase in other taxes or cuts in taxes and do not result in changes in social programs. Generally, except Scandinavia, there is a principle that using rates lower than an average is possible, but only in selected categories of taxes. If the tax authorities generally assume, in the entire tax system, a very low rate or even zero, they are voluntarily deprived of sources of public revenue and this automatically eliminates any of the activities of government structures, particularly in the area of social welfare.

The obvious effect is that any country seeking to attract and retain foreign investment pressures of tax competition is manipulating the rates of income tax from legal persons. The total loss in this way is compensated for by indirect taxes in particular (VAT/GST). This correlation is reaffirmed Singapore's Minister of Finance, indicating that the reduction in the rate of income 
tax from legal persons means a cost of $\$ 400$ million a year for each percentage point reduction. The alternative to such measures would increase the GST, which is $5 \%$. If, however, the rate is increased from $5 \%$ to $7 \%$, the budget will collect additional funds for the implementation of social programs and social issues. These announcements were finally made into reducing the rate of corporation tax by $2 \%$ age points to $18 \%$, and increasing the GST to $7 \%$.

Apart from reducing tax rates and widening the tax base, a significant change was the introduction in particular by the countries of Central and Eastern Europe a flat tax. Such reforms would greatly simplify the tax code and increase investment and economic growth. The nations that emerged from communism's collapse are leaders in the flat tax revolution. The flat tax is a way of jump-starting growth so that the income gap between Western and Eastern Europe is narrowed. Every time another nation adopts the flat tax and enjoys faster growth, it encourages other counties to follow this pattern (Edwards, Mitchell 2008, p. 63). What's more, developing countries have been just enthusiastic in the global tax competition, though they are often more appealing to MNEs because of their cheap labor and abundant natural resources.

\section{Fiscal Union as the Response on the global Tax Crisis}

The European Union on the international arena is seen through the prism of uniqueness, which is manifested in the fact that it is so far the only example of an integrated international group. It is characterized by features whose simultaneity and combination creates a new quality in economic, social and political terms, making the EU a unique, yet powerful partner in international relations.

The principles on the basis of which the idea of building a united Europe would lead to the creation of a competitive market within the EU while creating a foundation for welfare states such as through a strong and healthy public finances. Unfortunately, strong and healthy public finances in the EU and to some extent the concept of the Union threatened the international environment conditions in the very process of globalization. As indicated by M. Mrak, private sector operating in the highly competitive environment need clear rules of operation, stable macroeconomic environment, unrestricted access to imports, efficient economic and social infrastructure, and all these are requested from national governments (Mrak 2000, p. 8). Respecting these conditions during the dynamic process of globalization is extreme- 
ly difficult, and especially when autonomy and sovereignty are limited by the common solutions of the Treaties.

The four freedoms under the Treaty of 1957, which merged most of the countries of Europe in an economic and political organism due to the dynamic technological progress have generally implemented the principles of outside the EU. The principle of free movement of capital, goods, services and labour are now commonly applicable rules in the global economy regardless of the desire to belong to it.

In such circumstances, J. Stigliza seems to be extremely precise in capturing the essence of globalization, according to which globalization is deeper integration of the world. Globalization and digitalization have made resulted in market forces becoming so powerful that governments (...) are often not able to control them, while their limited ability to control the activities of the persons or companies of international agreements that encroach on the sovereign rights of the individual states to decision-making (Stigliz 2007).

Globalization has its share of both major successes and failures in a special way, revealing deregulation of public finances. One should also pay attention to a new phenomena that have emerged in connection with the creation of the euro area, the problem of moral hazard and free-riding, which result primarily from the strong monetary and economic ties.

With so much pressure from the international environment forcing changes in public finance systems of countries around the world strong and sound income can be quickly disrupted by the intensification of tax competition. The states that have protected its sovereignty in fiscal policy more than ever are open to international cooperation.

The question is whether the next stage of the EU integration in the form of fiscal union will be sufficient to restore discipline in public finances. The primary objective of a fiscal union to adopt more stringent fiscal rules, will protect the European Union (both as an institution and each country separately) from a new wave of economic crisis. The basic assumptions are: (i) to keep the state budget deficit below 3\% of GDP and public debt below 60\%. GDP, (ii) increased control over policing Brussels, financial discipline, (iii) to countries that do not comply with budgetary discipline to be imposed automatic penalties, (iv) about a penalty of $0.1 \%$ of country's GDP is to rule the EU Court of Justice. But, the criteria for fiscal discipline already have a place in the treaty regulations. The Stability and Growth Pact of 1997 and its reform in 2005, currently operate additional rules fulfil the above criteria to strengthen budgetary discipline. One of them is the requirement to achieve a close balance the budget or budget surplus in the public finances sector in the medium term.

Fiscal Union is expected to be a remedy for the crisis, but this is also a further harmonization of the tax. A classic fiscal union can by described as 
a transfer to the EU authorities a competence in tax collection and spending of revenues derived from them. This is a very precise way of integration. An example of a fiscal union may be the United States of America.

It seems unlikely that European Union countries deprive themselves to the bodies of their fiscal powers, which are in fact the foundation of national sovereignty. The fiscal Union, which is the subject of negotiations within the EU leaders, probably covers only certain elements of a classical fiscal union. The only concrete factor that reaches the public opinion, is a mechanism to discipline the Member States which exceed the permitted budget deficit. But such a mechanism is hardly to be regarded as a fiscal union.

From the perspective of countries offering favourable solutions in their tax systems further fiscal integration is not indicated. Favourable levels of taxation especially provided by the States of New Europe, is an asset perceived by entrepreneurs. The unification of taxes would deprive Poland and other countries of the Eastern and Central Europe of a major asset in the competition for investments. Tax policy is a response to the needs of state spending. Individual Member States have different policies when it comes to spending. It is difficult to introduce a uniform tax system, not aligning spending at the EU level. While tax harmonization across the EU seems to be a very difficult task, the unification of spending at EU level should rather be seen in terms of political fiction .

For years, a tax on businesses ${ }^{5}$ that unrestricted European Union directives (with only limit on co-ordination) has been of particular interest and has been a special component of the investment climate and also subject to tax competition. For years, Germany and France (the initiators of the fiscal union) have emphasized the need for harmonization of tax systems, particularly corporate taxes, as one of the key elements that allow to complete the European internal market of the European Union. It should be noted that in this respect, fiscal union is attempting to unify the corporate tax - once again. In the past, European governments have not demonstrated great enthusiasm for corporate tax harmonisation, and earlier proposals for greater co-ordination of corporate income taxes within the EU met with considerable resistance (Bond et al. 2000, p. 46).

Germany, France and other high-tax states also supported the establishment of an OECD committee which has focused on business taxation and 'harmful' tax competition. But the OECD agreement does nothing to prevent governments from engaging in international tax competition by lowering general corporate tax burdens. Indeed, it explicitly defends the choice to adopt whatever general level of corporate taxation a government prefers, even if the choice of a very low rate has undesirable competitive conse-

${ }^{5}$ These include Neumark Committee (1963), Van den Tempel (1971), European Commission (1967, 1975, 1980 and 1988) and Ruding Committee (1992). 
quences for other countries that wish to impose a higher level of corporate taxation. This reflects the interests of governments which wish to use tax incentives to attract FDI, and the reluctance of all governments to sacrifice policy-making autonomy in an area which has always been viewed as central to national sovereignty. All of these problems - income shifting, investment outflows, and the difficulty of reaching meaningful international agreements to restrain international tax competition - suggest that combining openness with high levels of corporate taxation is not a viable option for most states (McBride, Wiseman 2000, p.124).

Regardless of the "wishes" of politicians concerning the globalization, international community integrates into a single economic organism forcing verification of previous assumptions of socio-economic policy, including changes in tax policy. The global crisis has revealed a deepening of the 2007-2009 economic integration (unfortunately also in its negative aspect). Individuals and businesses have gained greater freedom to take advantage of the foreign economic opportunities. That, in turn, it increases the sensitivity of investment and location decisions to taxation. Edwards and de Rugy suggest the following solution: take the tax reforms to ensure that their economies remain attractive for investment, or/and to adopt defensive rules to prevent residents and businesses from enjoying lower tax rates abroad, or to harmonize taxes across countries and to restrict countries from offering tax climates that are too hospitable to foreign investment inflows. But those defensive responses to tax competition are a dead end. They do nothing to promote economic growth or reform inefficient tax systems. A more constructive response to tax competition would be to learn from foreign reforms and adopt pro-growth tax policies at home (Edwards, de Rugy 2002).

Places such as Ireland, Estonia, Hong Kong, and Switzerland6 illustrate that lower tax rates boost growth and improve tax compliance. They show that tax systems that are simpler and have lower rates liberate businesses to focus on creating jobs and wealth (Mitchell 2007).

Tax competition is now an integral part of the public finances and should be to taken in to account in the budgetary planning process. It plays a key role in selecting a business location - for example, tax considerations were the cause of transferring a substantial part of the German pharmaceutical industry in Ireland, while computer companies prefer to invest in Switzerland, and Australian consumers prefer to purchase software from Singapore.

Switzerland is a special case. The increasing interference of statist foreign regimes in its affairs convinced the Swiss government of the necessity of reinforcing bank secrecy and defending Switzerland's strong support of civil liberties. The Swiss government realized that a country the size of Switzerland could defend its independence only by means of clear and indisputable laws that would prohibit the violation of bank secrecy even under foreign pressure. A similar ideology is in the field of fiscal policy which is subject to intense pressure from the European Union, OECD, IMF. 
The discrepancies that have occurred in the territory of the Union on the taxation of becoming a kind of wedge in relations between Member States, disrupting the processes of integration. Hence, attempts are being made in the field of fiscal policy convergence, which might be the final component of asymmetric shocks, which EU member states will face. In a situation where European Union countries are using their own tax system to carry out functions of public finances and thus exerting influence on the condition of the economy and its attractiveness to potential investors, a key problem facing European Union is a tax competition. Krogstrup indicates that, despite the globalization of world economy, the European Union on the one hand is aware of the on-going trend, and on the other retains its autonomy (Krogstrup 2003). In the international arena, especially in the European Union, there is a fundamental problem in the long run if one leads a moderate policy of harmonization of the tax law that allow for the phenomenon of tax competition shaped by the market.

To protect the welfare state, the Union, through a process of tax harmonization, attempts to provide financial backing in the supply of public goods. Pathways may include the following: full harmonization of tax policy, the definition of minimum levels of tax rates, tax competition is controlled. It should be emphasizing, that the acceptance of tax competition involves only honest practices (OECD 2001), however, according to Kondo term is as vague as the term of international trade fair (Kondo 2002, p. 4).

From the initial announcement fiscal union will cover under harmonization process corporate tax. While other determinants of capital investment, such as the size of the economy, infrastructure, the quality of the labour force, regulatory practice and a strong rule of law also substantially affect investment, taxation plays a significant role (Mintz 2007).

Without a doubt, common solutions in terms of: statutory tax rate, tax base, amount of deductions, tax reliefs, progressivity of the tax rate will introduce a specific fiscal regime with its inherent consequences as an escape from the tax and the development of the informal economy.

Where taxes are high, businesses are more inclined to opt out of the formal sector. A recent study shows that higher tax rates are associated with fewer formal businesses and lower private investment. A ten percentage point increase in the effective corporate income tax rate is associated with a reduction in the ratio of investment to GDP of up to two percentage points and a decrease in the business entry rate of about one percentage point (Djankov el. 2010, pp. 31-64). 
Increased burdens of taxation and regulation, as well as the state of the "official" economy are important determinants of the shadow economy. The estimated weighted average informality in 162 countries around the world, including developing, Eastern European, Central Asia, and high-income OECD countries, is $17,1 \%$ of "official" GNP (Buehn, Schneider 2012, p. 139).

\section{Conclusions}

According to Willem Buiter (2007) financial crises are inherent to capitalism. Even though they can be very painful, it is an illusion that banking crises can be fully ruled out by better government regulation. In fact, a case can be made that perverse regulations, in combination with the creation of too much liquidity, played a key role in the creation of the current crisis. We would also not argue against government actions in case of a crisis. Effective government intervention may help the recovery of the financial sector. At the same time, many of the government actions taken in the current financial crisis were not effective, and may in fact have prolonged the crisis.

As the European Union heads down path toward a more complete integration, several economic policy questions have arisen and now remain without definitive response. Among these, perhaps none are as contentious as the future of taxation within the European Union. Fiscal policy including taxation remains one of the tools at the disposal of national governments in their efforts to influence their own economies. It is no surprise that the debate over taxation within the EU is a heated one. The main problem concerns whether regulated tax harmonisation or market driven tax competition is the best solution to awkward state of asymmetric tax rates that currently exists in the EU. The existing viewpoints run the gamut from entirely proharmonisation to pro-competition.

Competition does not imply that activities become more and more similar all around the world, quite the contrary: As a process of discovery - according to the words of Friedrich Hayek - competition induces producers to differentiate one from the other. Therefore, from this very general point of view, if ever, in a globalised world, one would consider that tax systems also have to be "globalised", it would imply tax competition and tax differentiation and not tax harmonisation or world taxation (Salin 2007).

Tax competition gives rise to the optimal tax system, which provides a rational trade-off between efficiency and distributive justice (as reflected in the choice of social welfare function). Within the European Union, competition in the field of taxation has beneficial effects. It may be fierce in some areas, but it still has institutional and political constraints. In case of a fiscal union, 
we are seemingly facing a real conundrum. The question is whether a fiscal union including the further process of tax harmonization is really necessary, as far as it is a political step.

\section{References}

Bond S., Chennells L., Devereux P.M., Gammie M.,Troup E. (2000), Corporate Tax Harmonisation in Europe: A Guide to the Debate. The Institute for Fiscal Studies.www.ifs.org.uk.

Buehn A., Schneider F. (2012), Shadow economies around the world: novel insight, accepted knowledge, and new estimates. "Interbational Tax and Public Finance", Vol. 19, No. 1.

Buiter W. (2007), Lessons from the 2007 Financial Crisis. CEPR Discussion Paper No. 6596. Center for Economic Policy Research.

Devereux M.P., Loretz S. (2012), What do we know about corporate tax competition? Article prepared on the Annual Congress of International Institute of Public Finance, Drezno.

Djankov S., Ganser T., McLiesh C., Ramalho R. Shleifer A. (2010), The Effect of Corporate Taxes on Investment and entrepreneurship, "American Economic Journal: Macroeconomics", Vol. 2, No. 3.

Edwards Ch. (2003), Tax Competition Spurs Globalization, USA “Today”, Vol. 131, Issue. 2694.

Edwards Ch., Mitchell D.J. (2008), Global Tax Revolution, CATO Institute, Washington.

Edwards Ch., de Rugy V. (2002), International Tax Competition. A 21st-Century Restraint on Government, "Policy Analysis", No. 431, Cato Institute, Washington.

Fox. W.F. (1998), Reengineering state and local revenue structures for the new econom, Proceedings of the Ninetieth Annual Conference on Taxation (Chicago, IL, November 1997).

Gałuszka J. (2011), Globalization, harmonization - the impact on corporate income tax [in:] K. Jajuga (ed.), Financial Sciences, No. 5, Research Paper of Wroclaw University of Economics, Wrocław.

Giddens A. (1990), The Consequences of Modernity, Stanford University Press: Stanford, CT.

Ter-Minassian T. (2007), Globalization, Financial Markets, and Fiscal Policy, Prepared by the Fiscal Affairs Department, International Monetary Fund, November 16.

Gomes P., Pouget F. (2008), Corporate Tax Competition and the decline of public investment, European Central Bank, Working Paper Series No. 928.

Grunberg, I. (1998), Double jeopardy: Globalization, liberalization, and the scal squeeze, "World Development", Vol. 26, No. 4.

Grubert H. (1998), Has globalization transformed the behavior of governments and taxpayers? Proceedings of the Ninetieth Annual Conference on Taxation (Chicago, IL, November). 
Iorwerth A., Danforth J. (2004), Is Investment Not Sensitive to its User Cost? The Macro Evidence Revisited, Working Paper 2004-05. Ottawa: Department of Finance.

Kirchgässner G., Pommerehne W.W. (1996), Tax harmonization and tax competition in the European Union: Lessons from Switzerland, "Journal of Public Economics", Vol. 60, No. 3.

Kondo S. (2002), Uncooperative Tax Havens: Little Cheats Will have to Repent, "International Tribune", May 10.

KPMG (2011), International Cooperative. Corporate and Indirect Tax Survey a Swiss Entity, September .

Krogstrup S.(2003), A Synthesis of Recent Development in the Theory of Capital Tax Copetition, EPRU Working Paper, February.

McBride S., Wiseman J. (2000), Globalization and Its Discontents, Macmillan. Basingstoke.

Mitchell, D.J. (2007), Corporate Taxes: America Is Falling Behind, “Tax \& Budget", No. 48.

Mitchell, D. (2013), OECD Launches New Effort to Undermine Tax Competition, "Tax and Budget" No. 68.

Mintz, J. M., Tarasov A. (2007), Canada is Missing out on Global Capital Market Integration, C. D. Howe Institute E-brief, Toronto: C. D. Howe Institute.

Mintz J.M. (2007), Tax Competitiveness Report: A Call for Comprehensive Tax Reform, No. 254, C.D. Howe Institute,

www.cdhowe.org.

Mooij R.A, Ederveen S. (2003), Taxation and Foreign Direct Investment: A Synthesis of Empirical Research, "International Tax and Public Finance", No. 10.

Mrak M. (2000), Globalization: Trends, Challenges and Opportunities for Counties in Transitio, United Nations, Vienna.

Neumann R., Holman J., Alm J. (2003), Globalization and Tax Policy, Andrew Young School of Policy Studies, Geortgia State University.

Neumann R., Holman J., Alm J. (2008), Globalization and Tax Policy, VERC Conference on the implications of Integration for Globalization, Wilfrid Laurier University.

OECD (2001), The OECD's Project on Harmful Tax Practices: The 2001 Progress Report, Paris.

OECD (2013), Addressing Base Erosion and Profit Shifting, http://www.oec d.org/ctp/BEPSENG.pdf

Owens J. (2006), Fundamental Tax Reform: an International Perspective, OECD's Centre for Tax Policy and Administration, www.oecd.org/ctp.

Salin P. (2007), The Case Against "Tax Harmonization”: The OECD and EU Initiatives, Liberales Institute. ww.taxcompetition.org

Tanzi V. (2000), Globalization, Technological Developments and the Work of Fiscal Termites, International Monetarny Fund, Working Paper.

Tanzi V. (2004), Globalization and The Need for Fiscal Reform in Developing Countries, Occasional Paper, IDB-INTAL, Buenos Aires.

Tanzi V. (2005), Fiscal Policy and Fiscal Rules in the European Union, Centre for Social and Economic Research, Studies \& Analyses No. 301, Warsaw. 
Paying Taxes (2009), The global picture, PriceWaterHouseCoopers and World Bank.

Paying Taxes (2012), The global picture, PriceWaterHouseCoopers and World Bank.

Sy W. (2012), Endogenous1 crisis and the economic paradigm, "Real-World Economics Review", No. 59 .

Stiglitz J.E. (2007), Wizja sprawiedliwej globalizacji, PWN, Warszawa 2007. 